\title{
ВИКОРИСТАННЯ СПЕЦАЛЬНИХ ЗНАНЬ ПІД ЧАС РОЗСЛІДУВАННЯ ЗЛОЧИНІВ У СФЕРІ СЛУЖБОВОї ДІЯЛЬНОСТІ
}

КУШІІТ Володимир Петрович - кандидат юридичних наук, доцент, доцент кафедри кримінального права і процесу Навчально-наукового Інституту права, психологіі та інноваційної освіти Національного університету «Јьвівська політехніка».

DOI:10.32782/LAW.2019.3.14

Статья посвящена раскрьттию понятия «специальнье знания». Обосновъвается необходимость использования специальных знаний при расследовании преступлений в сбере служебной деятельности. Освещаются основныле формы использования специальнъих знаний в области экономики в ходе досудебного расследования определеннъхх преступлений.

Ключевъе слова: специальные знания, преступления в сфере служебной деятельности, досудебное расследование, следственнъе (розъикнъие) действия.

\section{Вступ}

Відповідно до ст. 19 Конституції України органи державної влади та місцевого самоврядування, їх посадові особи зобов'язані діяти лише на підставі, в межах повноважень та у спосіб, що передбачені Конституцією та законами України. Ці конституційні приписи поширюються на всіх без винятку службових осіб, незалежно від того, чи є вони представниками законодавчої, виконавчої або судової гілок влади, виконують свої службові функції в державному апараті, органах місцевого самоврядування чи в громадських об'єднаннях, здійснюють службову діяльність у юридичних особах публічного чи приватного права [1] . Не має також значення службове становище особи, відомча чи галузева приналежність підприємства, організації, установи, сфера їх діяльності, організаційно-правова форма і форма власності, на підставі яких вони створені та функціонують. Повною мірою вимога діяти лише в межах, наданих їм повноважень, та у спосіб, передбачений законодавством, поширюється і на тих осіб, які хоча і не належать до службових, але сфера професійної діяльності яких пов'язана 3 наданням публічних послуг, бо надання таких послуг спрямоване на набуття, зміну чи припинення прав та/або обов'язків юридичних і фізичних осіб і тягне за собою наслідки правового характеру.

Постановка проблеми

Окреслена категорія злочинів 6 різноманітною, оскільки може вчинятися в різних сферах суспільного життя. Злочини у сфері службової діяльності є небезпечними за своїми наслідками та складними за механізмом вчинення. Відповідно способи вчинення злочинів у сфері службової діяльності також $\epsilon$ різними. Вони нерідко поєднанні з використанням новітніх технологій чи інших знань і навиків, що беззаперечно ускладнює процес з їх виявлення та розслідування. Зокрема, виникає необхідність використання спеціальних знань під час розслідування цих злочинів.

Аналіз останніх досліджень

Питання щодо визначення змісту спеціальних знань та форм їх використання у досудовому розслідуванні неоднократно виступали предметом дослідження у працях таких науковців, як $\mathcal{\lambda}$. С. Ароцкер, Р. С. Бєлкін, А. І. Вінберг, Є. В. Додін, Н. Я. Дондик, 


\section{Кримінальне право, кримінальний процес та криміналістика}

А. В. Калаянова, О. Д. Калаянова, Г. А. Карпенко, М. В. Салтевський, В. Ю. Шепітько, М. Г. Щербаковський, М. П. Яблоков та ін. Великий вклад згаданих учених не викликає сумніву у наукові здобутки з розвитку та вдосконалення методик використання спеціальних знань під час розслідування злочинів. Однак, чимало питань залишилось невирішеними. А саме, більшість напрацювань досліджують проблематику використання спеціальних знань у цілому (поняття, завдання, принципи, форми, функціонування експертних установ тощо), а інші - виключно через призму проведення відповідних експертиз. Проте, мало приділяється уваги ретельному дослідженню інших, окрім проведення судових експертиз, форм залучення спеціальних знань для забезпечення ефективності розслідування злочинів. Особливо, для розслідування злочинів у сфері службової діяльності.

Метою цієї статті є висвітлення особливостей використання спеціальних знань під час розслідування злочинів у сфері службової діяльності.

\section{Виклад основного матеріалу}

Злочини у сфері службової діяльності в переважній більшості скоюють службові особи з використанням свого становища, впливу, зв'язків тощо. Причому чимала частка цих злочинів направлена на заволодіння певними матеріальними статками. Відповідно значний масив слідової картини знайде своє відображення в різного роду документації, в тому числі бухгалтерського обліку та фінансової звітності. Окрім того, способи вчинення окреслених злочинів реалізуються шляхом проведення різних господарських операцій. Отже, слідчому потрібна допомога фахівця з економічних питань. Адже без неї кримінальне провадження буде малоефективним, а в деяких випадках - взагалі може зайти в глухий кут.

Так, спеціалістом у кримінальному провадженні є особа, яка володіє спеціальними знаннями та навичками застосування технічних або інших засобів і може надавати консультації під час досудового розслідування і судового розгляду з питань, що потре- бують відповідних спеціальних знань і навичок [2]. При цьому, ці консультації можуть надаватися як самостійно (організаційна форма), так і під час проведення окремих слідчих (розшукових) дій і експертиз (процесуальна форма). Тому вважаємо, що слідчий у своїй діяльності повинен керуватися наступними рекомендаціями 3 алгоритмізації використання спеціальних знань під час розслідування злочинів у сфері службової діяльності.

1. Планування. На наш погляд, успішна реалізація будь-якої діяльності неможлива без попереднього планування. Саме планування дозволяе визначити основні напрямки діяльності, в даному випадку 3 розслідування злочинів у сфері службової діяльності, та шляхи досягнення бажаного результату. Таким чином відбувається координування кримінального провадження. На цьому етапі доцільно отримати консультативну допомогу від спеціалістів у галузі економічних знань щодо можливих способів вчинення конкретного (-их) злочину (-ів), їх слідів і способів їх виявлення й дослідження. А саме, слід уточнити специфіку функціонування відповідного інституту, правову регламентацію цієї сфери життєдіяльності, особливості проведення конкретних господарських операцій і їх документування, перелік документів, з якими слід ознайомитися, існуючі методи перевірки правильності проведення господарських операцій, ведення звітності (бухгалтерської, фінансової, податкової, статистичної тощо) та їх можливості. Отримавши таку інформацію, слідчий безпосередньо планує розслідування конкретного злочину у сфері службової діяльності.

2. Допит спеціаліста. Спілкування зі спеціалістом пропонуємо процесуально оформлювати, щоб результати консультацій могли бути використані в якості доказової бази. Тому вважаємо, що консультативну бесіду слід проводити в межах такої слідчої (розшукової) дії як допит спеціаліста в якості свідка. Таким чином, роз'яснення спеціаліста будуть закріплені в протоколі допиту, що надасть більшої наочності в розумінні механізму вчинення злочину у сфері службової діяльності, механізму слідоутворення 
та дослідження слідів іншим учасникам кримінального провадження.

3. Як уже зазначалося, розслідування злочинів у сфері службової діяльності насамперед передбачає «роботу» 3 різними документами. Відповідно слідчому потрібно отримати тимчасовий доступ або їх тимчасово вилучити. А в клопотанні, яке оформлюеться для отримання дозволу на застосування вказаних заходів забезпечення кримінального провадження, потрібно обгрунтувати необхідність такого застосування, вказати конкретний перелік документів і місце їх знаходження. I тут знову не обійтися без допомоги спеціаліста у галузі економічних знань, адже він пояснить, що таке бухгалтерський облік і фінансова звітність, яким чином вона ведеться в конкретному підприємстві та яким закладам надається така інформація.

Зокрема, особа, яка провадить розслідування злочинів у сфері службової діяльності, повинна знати, що бухгалтерський облік - це процес виявлення, вимірювання, реєстрації, накопичення, узагальнення, зберігання та передачі інформації про діяльність підприємства зовнішнім та внутрішнім користувачем для прийняття рішень. Бухгалтерський облік є обов'язковим видом обліку, який ведеться підприємством, а фінансова, податкова, статистична та інші види звітності, що використовують грошовий вимірник, грунтуються на даних бухгалтерського обліку.

Відповідно фінансова звітність - бухгалтерська звітність, що містить інформацію про фінансове становище, результати діяльності та рух грошових коштів підприємства за звітний період [2].

У бухгалтерському обліку повинні фіксуватися факти здійснення всіх господарських операцій у первинних документах. Відповідальність же за організацію бухгалтерського обліку, збереження оброблених документів, регістрів і звітності протягом встановленого терміну, але не менше трьох років, несе власник або уповноважений орган (посадова особа), який здійснює керівництво підприємством згідно з установчими документами.

Зазначене вказує на те, що слідчий повинен отримати доступ і ознайомитися із за- сновницькою та установчою документацію, щоб з'ясувати завдання функціонування суб'єкта господарювання, а також на кого покладено обов'язок здійснювати контроль і нести відповідальність за організацію бухгалтерського обліку. 3 цією ж метою необхідно ознайомитися з наказом про призначення на посаду, посадовою інструкцією, трудовим договором чи контрактом.

Також для слідчого не менш важливим є завдання з'ясувати питання щодо форми організації ведення бухгалтерського обліку на підприємстві, адже залежно від цього й буде відрізнятися алгоритм його діяльності під час розслідування злочинів у сфері службової діяльності. Зокрема, можливі наступні варіанти ведення бухгалтерського обліку на підприємстві:

- введення до штату підприємства посади бухгалтера або створення бухгалтерської служби на чолі 3 головним бухгалтером;

- користування послугами спеціаліста 3 бухгалтерського обліку, зареєстрованого як підприємець, який здійснює підприємницьку діяльність без створення юридичної особи;

ведення на договірних засадах бухгалтерського обліку централізованою бухгалтерією або аудиторською фірмою;

самостійне ведення бухгалтерського обліку та складання звітності безпосередньо власником або керівником підприємства [3].

Останній варіант ведення бухгалтерського обліку є неприйнятним для бюджетних установ і для підприємств, звітність яких повинна оприлюднюватися.

Вищенаведене вказує на необхідність дослідити установчу документацію на предмет з'ясування облікової політики підприємства, форми бухгалтерського обліку (яка конкретна система регістрів обліку використовується, який порядок і спосіб реєстрації й узагальнення інформації в регістрах обліку), системи та форми внутрішньогосподарського (управлінського) обліку, звітності і контролю господарських операцій, обсягу прав конкретних працівників на підписання бухгалтерських документів, правил документообігу та технології обробки облікової інформації, додаткової системи рахунків 


\section{Кримінальне право, кримінальний процес та криміналістика}

i регістрів аналітичного обліку, наявності на окремому балансі філій, представництв, відділень чи інших відокремлених підрозділів, які зобов'язані вести бухгалтерський облік, факту включення показників бухгалтерського обліку відокремлених підрозділів до фінансової звітності підприємства, факту застосування (використання) міжнародних стандартів. Слід вияснити, у функціональні обов'язки якої посадової особи входить ведення бухгалтерського обліку підприємства - головного бухгалтера чи іншої особи, на яку покладено ведення бухгалтерського обліку. До того ж варто ознайомитися із методологією бухгалтерського обліку та встановленими строками подання фінансової звітності. Для вирішення цих питань варто дослідити за участю спеціаліста у галузі економічних знань відповідну документацію.

Також потрібно ознайомитися зі штатним розписом установи, зокрема, 3 метою 3'ясування наявності в штаті такого відокремленого підрозділу, як бухгалтерська служба, чи можливо виконання обов'язків такої служби покладено на спеціаліста. Залежно від відповіді на це питання й буде різнитися коло документів, 3 якими слід ознайомитися слідчому, - це буде положення про бухгалтерську службу чи посадова інструкція спеціаліста, на якого покладено виконання обов'язків бухгалтерської служби.

Слід ретельно дослідити особову справу головного бухгалтера для з'ясування дотримання вимог у частині правильного підбору кандидата на роботу, а саме перевірити документи, що підтверджують наявність в особи вищої освіти відповідного професійного спрямування, стажу роботи за фахом i досвіду роботи на керівних посадах. До того ж варто ознайомитися з актом внутрішньої перевірки стану бухгалтерського обліку та звітності, яка проводилася у разі звільнення попереднього та призначення на посаду діючого головного бухгалтера.

Так як на підприємствах регулярно 3 контрольною функцією проводяться інвентаризації активів і зобов'язань, слідчому потрібно отримати доступ до їх матеріалів. Ці матеріали містять у собі відомості про достовірність даних бухгалтерського обліку та фінансової звітності підприємства, а саме: документально підтверджують наявність, стан і оцінку активів і зобов'язань підприємства. Зокрема, перед складанням річної фінансової звітності обов'язкове проведення інвентаризації активів та зобов'язань підприємства. Також проведення інвентаризації обов'язкове у разі: передачі майна державного підприємства в оренду, приватизації майна державного підприємства, перетворення державного підприємства в акціонерне товариство; зміни матеріально відповідальних осіб (на день прийманняпередачі справ); встановлення фактів крадіжок або зловживань, зіпсуття цінностей, а також за приписом судово-слідчих органів; пожежі, стихійного лиха або техногенної аварії; ліквідації підприємства, а також в інших випадках, передбачених законодавством [4]. Тому потрібно перевірити факти проведення інвентаризацій за вказаних обставин і ознайомитися 3 їх матеріалами. Спеціаліст повинен допомогти з'ясувати, чи правильно була проведена інвентаризація, чи відповідають результати іншим обліковим документам і які порушення під час іï проведення були допущені.

Окрім інвентаризації, з метою перевірки правильності ведення бухгалтерського обліку та фінансової звітності в установі може проводитися аудиторська перевірка. У такому разі слід отримати доступ до аудиторського звіту.

4. Підставою для бухгалтерського обліку господарських операцій є первинні документи, які фіксують факти здійснення господарських операцій. А для контролю та впорядкування оброблених даних на підставі первинних документів можуть складатися зведені облікові документи. Ось чому слідчий повинен знати вимоги до оформлення цих документів, адже під час огляду потрібно буде встановити факт їх дотримання чи порушення. I до проведення цієї слідчої (розшукової) дії знову ж таки потрібно залучати спеціалістів.

Тож вказані документи можуть бути складені як на паперових, так і на машинних носіях. Проте, в обох випадках облікові документи повинні мати наступні обов'язкові реквізити: назву документа (форми); дату та місце складання; назву підприємства, 
Кушпіт В.П. - Використання спеціальних знань під час розслідування злочинів...

від імені якого складено документ; зміст та обсяг господарської операції, одиницю виміру господарської операції; посади осіб, відповідальних за здійснення господарської операції та правильність її оформлення; особистий підпис або інші дані, що дають змогу ідентифікувати особу, яка брала участь у здійсненні господарської операції. Залежно від характеру операції та технології обробки даних до первинних документів можуть бути включені додаткові реквізити: ідентифікаційний код підприємства, установи 3 Державного реєстру, номер документа, підстава для здійснення операцій, дані про документ, що засвідчує особу-одержувача тощо [3; 4]. Підпис може бути скріплений печаткою. Первинні документи складаються на бланках типових і спеціалізованих форм, затверджених відповідним органом державної влади. Якщо використовуються самостійно виготовлені бланки, то первинні документи повинні містити обов'язкові реквізити чи реквізити типових або спеціалізованих форм. У випадку віднесення бланків первинних документів до бланків суворої звітності, слідчому необхідно звернути увагу на наявність і зафіксувати нумерацію та спосіб іiі нанесення. Взагалі доцільно максимально детально оглянути й зафіксувати способи складання первинної документації, щоб з'ясувати їх відповідність встановленим правилам документального забезпечення записів у бухгалтерському обліку. Як приклад, це необхідність обов'язкового перекреслювання вільних рядків; підписування первинних документів визначеним обмеженим колом осіб; наявність відмітки на документах, що пройшли обробку; обов'язкове погашення штампом або ручним надписом «Одержано» або «Сплачено» із зазначенням дати всіх документів, що додаються до прибуткових і видаткових касових ордерів; помилки, що створені ручним способом, виправляються коректурним способом тощо. Що ж стосується виправлення помилок в облікових регістрах за минулий звітний період, то вони виправляються спеціальним способом,який називається «сторно». Цей спосіб передбачає складання бухгалтерської довідки, в яку помилка заноситься червоним чорнилом, пастою кулькових ручок тощо або із знаком «мінус», а правильний запис заноситься чорнилом, пастою кулькових ручок тощо темного кольору. При цьому, довідка має наводити причину помилки, посилання на документи та облікові регістри, в яких допущено помилку, і підписується працівником, який склав довідку, та після іï перевірки - головним бухгалтером. Виправлення помилки повинно бути обумовлено надписом «виправлено» та підтверджено підписами осіб, що підписали цей документ, із зазначенням дати виправлення. А от у документах, якими оформлені касові і банківські операції та операції з цінними паперами, виправлення не допускається [5].

Інформація, що міститься в первинних документах, систематизується на рахунках бухгалтерського обліку в регістрах синтетичного й аналітичного обліку шляхом подвійного запису їх на взаємопов'язаних рахунках бухгалтерського обліку. При цьому, регістри повинні мати назву, період реєстрації господарських операцій, прізвища i підписи або інші дані, що дають змогу ідентифікувати осіб, які брали участь у їх складанні. Забороняється робити будь-які виправлення записів у первинних документах і регістрах бухгалтерського обліку.

Результати бухгалтерського обліку використовуються під час формування фінансової звітності. Тому часто виникає потреба в співставленні відомостей, відображених у документах бухгалтерського обліку (які саме було вище висвітлено) і фінансової звітності. Що ж стосується останньої, то такого роду звітність, окрім бюджетних установ, представництв іноземних суб'єктів господарювання та суб'єктів малого підприємництва, включає в себе: баланс, звіт про фінансові результати, звіт про рух грошових коштів, звіт про власний капітал і примітки до звітів. А для представництв іноземних суб'єктів господарської діяльності та суб'єктів малого підприємництва фінансова звітність включає в себе тільки баланс і звіт про фінансові результати. У разі наявності дочірніх підприємств підприємство зобов'язане складати та подавати консолідовану фінансову звітність. Центральні органи виконавчої влади подають, окрім власної, ще й зведену фінансову звітність щодо всіх підприємств, 


\section{Кримінальне право, кримінальний процес та криміналістика}

що належать до сфери їх управління. Відповідно до всіх вказаних документів потрібно отримати або тимчасовий доступ, або їх тимчасово вилучити, потім провести їх слідчий огляд (за участю спеціаліста) і за необхідності направити на відповідну експертизу.

Вкотре акцентуємо увагу, що спеціаліст допоможе слідчому швидше й якісніше провести огляд вищенаведеної документації, оскільки йому відомі вимоги до такого роду документообігу, а отже, можливі порушення та їх прояви.

За результатами проведення слідчих оглядів і інших слідчих (розшукових) дій слідчий направляє документи на відповідні експертизи задля вирішення питань із залученням спеціальним знань. Зокрема, задля з'ясування правильності проведення господарських операцій, перевірки відповідності порядку ведення бухгалтерського обліку відповідним Державним стандартам призначається судово-бухгалтерська експертиза; щоб з'ясувати фінансовий стан підприємства, наявність заборгованостей, можливі шляхи їх погашення, чи цільовим є використання кредитних коштів тощо - фінансово-кредитна експертиза. Нерідко під час розслідування злочинів у сфері службової діяльності слідчий стикається 3 необхідністю одночасного залучення фахівців і у сфері судової бухгалтерії, і у фінансовій галузі.У таких випадках рекомендується призначати комплексну судово-економічну експертизу.

3 кожним роком усе більше вкорінюеться електронний документообіг, у тому числі й у сфері службової діяльності. У зв’язку 3 цим актуальним стало дослідження як електронних документів в цілому, так електронних підписів, електронних позначок часу зокрема, а також електронних повідомлень, веб-сайтів. Тому під час розслідування злочинів у сфері службової діяльності виникає потреба в проведенні комплексної комп'ютерно-технічної та судово-бухгалтерської експертизи.

\section{Висновки}

Отже, складний механізм вчинення злочинів у сфері службової діяльності обумовлює необхідність використання спеціальних знань під час розслідування цієї категорії злочинів задля вирішення основних завдань кримінального провадження. Зокрема, використання спеціалістів дозволяє своєчасно виявити всі сліди злочину у сфері службової діяльності та ефективно їх дослідити.

\section{Мiтература}

1. Про поняття та порядок створення юридичних осіб публічного та приватного права див. статті 81, 87 ЦК. URL: https:// zakon.rada.gov.ua/rada/show/v4643563-06.

2. Кримінальний процесуальний кодекс України: Закон України від 13.04.2012 № 4651 URL: https://zakon.rada.gov.ua/laws/ show/4651-17.

3. Про бухгалтерський облік та фінансову звітність в Україні : закон України від 16.07.1999 № 996 URL: https://zakon.rada. gov.ua/laws/show/996-14.

4. Про затвердження Порядку подання фінансової звітності : постанова Кабінету міністрів України від 28.02.2000 № 419. Офіційний вісник України. - 2000. - № 9. - Стор. 21. - Стаття 344. - Код акту 15065/2000.

5. Про затвердження Положення про документальне забезпечення записів у бухгалтерському обліку : наказ Міністерства фінансів України від 24.05.1995. № 88 URL: http: //zakon4 .rada. gov.ua/laws/show/z016895

\section{USE SPECIAL KNOWLEDGE IN THE FIELD OF THE INVESTIGATION OF CRIMES RELATED SERVICE ACTIVITY}

According to article 19 of the Constitution of Ukraine public authorities and local selfgovernment, their officials must act only on the basis, within powers and in the way provided by the Constitution and laws of Ukraine. These constitutional provisions apply to all without exception officials, regardless of whether they are representatives of legislative, executive or judicial branches of government performing their official functions in the state apparatus, the local authorities, or public associations engaged in service activities in legal entities of public or private law [1]. A value does not have official position of person also, department or branch belonging of enterprise, organization, 


\section{АНОТАЦІЯ}

у статті розкривається зміст поняття спеціальних знань. Обгрунтовується необхідність використання спеціальних знань під час розслідування злочинів у сфері службової діяльності. Висвітлюються основні фборми використання спеціальних знань під час досудового розслідування окреслених злочинів.

Ключові слова: спеціальні знання, злочини у сбері службової діяльності, досудове розслідування, слідчі (розшукові) дї.

establishments, sphere of their activity, legal form and pattern of ownership, on the basis of that they are created and function. The full extent of the requirement to act only within their powers and in the way provided by law, extends to those persons who although not related to service, but the sphere of professional activities connected with the provision of public services since the provision of such services aimed at acquisition, changing or termination of rights and/or obligations of legal and natural persons and shall attract the consequences of a legal character.

Most crimes in the sphere of service activity are committed by officers using their position, influence, relationships and so on. Moreover, a large proportion of these crimes aimed at acquisition of some material possessions. Accordingly, a large amount of trace pattern will be reflected in all sorts of documents, including accounting and financial reporting. In addition, methods of committing outlined crimes are implemented through various business transactions. And, therefore, the investigator need expert help on economic issues. Because without such help the criminal proceedings will be ineffective.

In this regard the article reveals the meaning of special knowledge. The necessity of using special economic knowledge in the investigation of crimes related to service activity is substantiated. The basic forms of using specialized knowledge in economics during the preliminary investigation of outlined crimes are highlighted.

Crimes in the sphere of office activity in the vast majority do officials using their position, influence, relationships, and others like that. Moreover, a large proportion of these crimes are aimed at mastering certain material conditions. In accordance, a significant array of trace pattern will be reflected in various documentation, including accounting and financial reporting. In addition, the methods of committing these crimes was being realized through different economic operations. So, the investigator need expert help on economic issues. Because without it the criminal proceedings will be ineffective, and in some cases may need to come to a standstill.

Key words: special knowledge, crimes related service activity, pre-trial investigation, investigative (search) actions. 